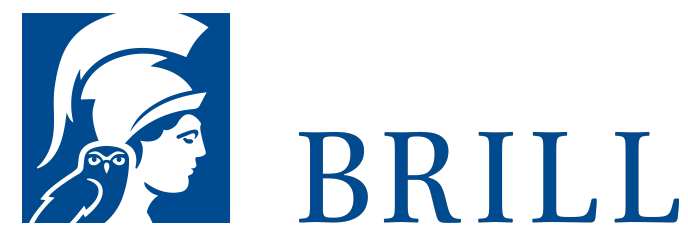

\title{
Die USA und der islamistische Terrorismus
}

\section{Herausforderungen im Nahen und Mittleren Osten}

Author: Lars Berger

Der Konflikt zweier Welten: Der islamistische Terrorismus und der Anti-Terrorkrieg der USA stehen seit dem Attentat vom 11. September 2001 weltweit im Mittelpunkt öffentlichen Interesses. Lars Berger, Amerika-Experte und Islamwissenschaftler, legt, gestützt auf einen reichen Fundus amerikanischer und arabischer Quellen, die erste umfassende Darstellung über das Wechselspiel zwischen der Außen- und Innenpolitik der USA, der Entwicklung in Nah- und Mittelost und den Strategien des islamistischen Terrorismus vor. Ihr zeitlicher Rahmen erstreckt sich vom ersten Anschlag auf das World Trade Center 1993 über den Terrorakt vom 11. September und Afghanistan bis zum Irak-Krieg George W. Bushs und seinem offenkundigen Scheitern. Im Mittelpunkt der Arbeit steht die Analyse des Zusammenhangs zwischen dem strategischen Kalkül und den Aktionen der islamistischen Terroristen, den Reaktionen der Öffentlichkeiten und Regierungen in den USA und der arabischen Welt und den Gegenstrategien der Präsidenten Clinton und George W. Bush innen-, außen- und sicherheitspolitisch. Ein Buch, dem weite Beachtung gewiss ist!

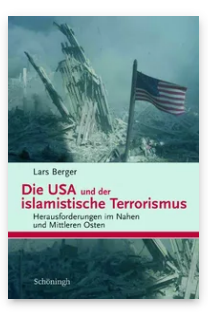

Pages: 481

Seiten

Language:

German

Subjects:

Economics \&

Political Science, Social Sciences

Publisher: Brill |

Schöningh

E-Book (PDF)

Released online:

29 Oct 2019

ISBN: 978-3-

657-76369-6

List price

US.SD \$30.00

Hardback

Publication date:

20 Jun 2007

ISBN: 978-3-

5o6-76369-3

List price

USD \$30.00 
For more information see brill.com

Order information: Order online at brill.com +44330 333 0049 | customerservices@brill.com Submission information: brill.com/authors

Titles published by Brill | Fink, Brill | mentis or Brill | Schöningh: +49(o)715413279216| brill@brocom.de 